\title{
Fish Resource Exploitation in The Besuki Region During The Pre-New Order period
}

\author{
Nawiyanto \\ Department of History, Faculty of Cultural Sciences \\ University of Jember \\ Jember, Indonesia \\ nawiyanto.sastra@unej.ac.id
}

\begin{abstract}
This article discusses the fishing economy of the Besuki region during the pre-New Order period. The major questions to be addressed with here are how the fish resources extraction developed in the region across time and how the region was transformed into a leading fishing complex. Using a wide range of historical source materials, the article argues that the development of the fisheries exploitation was induced by the presence of Dutch and Japanese fishers making use of better fishing technologies and the increase in number of fishing vessels operating in the region waters especially among the local fishers. This development brought a remarkable increase in catches and enabled the Besuki region to export fish products to other places, different from its earlier position as a fish importing area.
\end{abstract}

Keywords-fishing operations, fishing technology, Besuki residency, pre-New Order period

\section{INTRODUCTION}

Fisheries sector has occupied an important position in the economy of Besuki residency. The development of marine resources exploitation transformed the region into a leading center of marine fishery. Muncar was recognized as the second biggest fishing complex in Indonesia after Bagan Si Api-Api in Sumatra [1]. Despite the major position in the fish resources extraction, the historical development of fisheries in the region remains relatively unexplored. This fact is strikingly contrastive to the plantation sector of the region, that has attracted much scholarly attention, resulting in a great body of historical knowledge and well-established explanations on many aspects of the sector $[2,3,4]$. The existing studies on the fisheries of the region have focused mainly on the contemporary period. Emmerson's work discusses the social unrest among an early 1970s Muncar fishing community [5,6]. Attention has also been paid to such issues as social life, social networks, and socio-economic change during the 1970s fishing modernization [7,8].

The growing scholarly interests in the issues could not be separated from the modernization process taking place in the fishing sector. From around 1970, the region's fisheries entered a new stage of development, characterized by a strong intervention by the government under the so-called 'fishing modernization' intended to bring about improvement in the livelihood of fishing households by increasing catches. In contrast to the growing number of synchronic studies on fishing communities in the Besuki residency especially in the New Order era, little has been known of how fish resources extraction developed in the region across time and how the transformation of the region into a leading fishing complex took place. The questions remain relatively unexplored until today. By answering the two questions, the article is expected to provide a better understanding of the transformation of the Eastern Salient of Java into a leading fishing complex and the major factors behind the process?

The theoretical framework which informs the argument of the present article comes primarily from frontiers theories conceptualized by Flannery and Butcher. Fisheries are a biologically renewable resource, meaning that continuous extraction can be done. Sustainable fisheries, however, require a certain level of extraction. Beyond this point extractions would cause resource depletion and eventually lead to a closure of the fishing frontier when there are no longer available new areas with the same capacity for expansion. The extraction of fish resources depends largely on the demographic, commercial, and technological factors. Demographic and commercial factors play an instrumental role in creating demand for fish products, while technology facilitates fish resources extraction. More developed technologies can lead to a more intensified extraction of fish resources $[9,10]$.

\section{RESULTS AND DisCUSSION}

\section{A. Fishing Operations}

Fishing communities emerged in many places along the coastal areas of Besuki. The fishing communities in Besuki consisted of mainly Madurese and Javanese but there were minority groups of Buginese-Mandarese and Chinese [11]. The Mandarese were the descendants of the pre-1870 migrants who settled in Puger and Besuki, whereas the Buginese came to Muncar in the late 1950s [12] The two ethnic groups are well-known for their marine orientation. In absolute terms, from 1870 to 1970 the number of people engaged in fisheries grew across the Besuki region. In Banyuwangi it increased 
considerably from 1,000 fishers in 1903 to 12,000 fishers in the early 1970s, and in Panarukan from 3,500 fishers to 9,800 fishers $[13,14]$. The same trend presumably applied to Jember, where in 1903 there were 600 fishers. The proportion of fishers to the total population grew from around 0.7 per cent to 1 per cent in Banyuwangi and from 1.40 per cent to 2.30 per cent in Panarukan $[15,16]$.

Fishing developed in various places, but the northern seas seem to have initially been the focus. G.N. Verloop suggested a total revenue of $f 3.5$ million on the north coast of Besuki around 1870, but only $f 1.8$ million for Banyuwangi [17]. The 1880s annual reports from Besuki confirmed that there were more developed fisheries on the northern coast than on the southern and eastern coasts [18]. The distribution of the fishing villages reflected this reality too. In the early 1900 s there were 54 fishing villages on the northern coast, whereas in Banyuwangi there were 22 fishing villages, located largely on the eastern coast. On the south coast of Jember, only 4 fishing villages were reported [13]. Apart from the higher population size, the dominant position of the north coast's fisheries was partly due to the physical aspects. In the southern water, by contrast, giant waves posed a danger [13]. Accidents were reported to have often occurred and its danger has been reflected in the names of sites along the coast, such as corpse rocks (watu mayit) and the gate of death (pelawang maut) [19].

Each area seems to have had a special feature, besides sharing several catches in common. The major catch in the northern water was layang. During the layang season, as found in Panarukan, pickled fish-making activities (pindang), flourished [20]. But in Banyuwangi, lemuru (Bali sardinella, Clupea longiceps) was the primary catch. An estimate suggested that in the 1960s lemuru made up around 70 per cent of the total catches in Muncar [21]. The Bali Strait has been regarded as the best lemuru habitat [22]. In the southern water fish captures included a variety of species, but there was no single dominant catch [13]. In general, the major commercial catches in the region were layang and lemuru [23]. Apart from the special characteristics from one locality to another, times of good and bad catches through the year characterize fishing operations across the region. Catches also varied considerably between years. Unsurprisingly, rites played an important role in the region's fishing life in securing the people's fragile marine-based livelihood [19].

Among the region's fishing communities, a catch sharing system was common. Under this system, the fishing crew obtained an agreed portion of the catches and their revenues were determined by catches and fish prices, rather than a fixed wage. It meant that the risk of fishing operation was distributed among all those involved in the venture and the risk to capital owners, therefore, was minimized. Dietz [24] recognized in 1923 that the catch sharing system was more effective in sustaining working spirit among the Madurese fishing crew, indicating a greater possibility of maximizing the income opportunity for the fisher. There was a diverse catch-sharing arrangement, but almost certainly the capital owners (pengambak and juragan darat) took the largest portions [25]. In 1905 about 33-42 per cent of the catch in the Besuki district went to the capital owners, while the rest of the catch was shared among the crew [13].

Besides the continuance of traditional institutions, notable developments took place from the 1950s. Some fishers began to utilize social organizations as a means of coping with livelihood vulnerability. On the initiative of Sumadji Irawan, a fishing cooperative was established in 1951 in Muncar, called Menak Djinggo [26]. Although the primary objective was to protect fishers' interest against Chinese fish traders, the cooperative also provided financial assistance to fishers for resuming their operations in case of accidents at sea [27]. In Besuki such an organization was clearly a post-colonial phenomenon, though in other parts of Java it had much earlier developed, around the 1910s [28]. Although the fishing organizations did not always succeed in improving the fishers' livelihood, the use of such an organization was a new development in Besuki.

Both coastal and deep-sea fishing operated in Besuki, as indicated by the presence of mayangan and non-mayangan boats which were different in terms of size, construction materials, fishing gears and operation areas. Around the early 1900s the mayangan fishing was more common in the northern than in the eastern and southern waters [13]. In the latter two areas, coastal fishing with smaller size, non-mayangan boats predominated. Such boats were believed to be more suitable and safer for fishing operations in areas where giant waves and sheer reefs occurred [29]. The reach of the fishing technologies, however, remained limited. In Java the windpowered mayangan boats could hardly operate beyond $90 \mathrm{~km}$ from the coastline and fishing operations were usually run in areas between 40 to 50 $\mathrm{km}$ from the coastline [30]. Combined with fishing nets useful mostly for capturing pelagic fish, the existing technologies could not extract fish stocks located in deeper layers and more distant fishing grounds [31]. It was estimated in 1917 that only 25 per cent of Java's fishing grounds, mostly near the coast, was already used [32].

Unsurprisingly, in contrast to the region's strong export-oriented agriculture, the fisheries of Besuki were more local-oriented. In 1885 the resident of 
Besuki stated that the fish catches were locally marketed [18]. Another report revealed in 1905 that the fish catches of Puger were channeled to the other districts of Jember, which also became the market destination for fish products from Banyuwangi, while Bondowoso absorbed fish from the northern coast. But with the growing population [33], the local production was apparently insufficient and fish imports became necessary. Dried fish imports originated mainly from Madura, Makassar, Banjarmasin, and Palembang, annually reaching about 3,900 picol (240 tons) in the early $1900 \mathrm{~s}$, but smaller quantities of fish came from Bali and Sumbawa [13]. In 1920 Ch.O. van der Plas noted that Besuki was one of the primary markets for fish exports from the Sapudi and Kangean islands of Madura [34].

From the mid-1920s, Japanese and Dutch fishing fleets became involved in the fish resource exploitation. These foreign fishers employed more developed boats and fishing gear. This development was induced by the setting up of colonial policy designed to promote domestic industry and to reduce dependency on fish imports [25]. Patchy evidence suggests the activities of Japanese fishers in the region, including reef fishing in the Bali Straits [26]. This activity was part of the growing Japanese interest in the Indonesian fisheries from the mid1920s. The Japanese operated with steam-powered boats, trawler and muroami nets designed for reef fishing [36]. The moves were motivated by the fastgrowing fishing industry in Japan and the emerging overfishing problem, which led to tighter competition for fish resources. The Japanese fishers confronted restrictions imposed by the Soviet and Chinese governments and were forced to search for new fishing frontiers elsewhere. Through various investigations the Japanese fishers had been equipped with an understanding of the fish resources in Indonesian waters [37].

The interest of the Dutch fishers in exploiting the fish resources in Besuki had already emerged in the early 1900s. In 1913 Broersma noted a European-run fishing venture in Puger. However, the activity soon discontinued after the loss of capital from a sea accident and the owner failed to resume his business [38]. The interest was only renewed around 1930, following the sluggishness of the fisheries in the Netherlands. Poortman, a director of the fishing company at Maassluis, in cooperation with Pot, a herring fisherman at Vlaardingen, decided to shift their operation to colonial Indonesia [39]. Following the government's approval, a Dutch fishing company was established with its center in Jakarta. This company also operated in the Besuki waters and a fish processing factory was set up in Banyuwangi [25] The capacity of the Dutch- and Japanese-run fishing ventures in the region is unknown but might have been quite large.

The operations of modern fishing seem to have boosted the size of fish catches. The marine fisheries of Besuki grew considerably, symbolized by the emergence of the Muncar fishing complex as its center [20]. The best lemuru production in Muncar was achieved in 1938, reaching 20,000 tons. This development raised optimism that Muncar was a big competitor for the fish-producing center of Siam [40]. There was a radical change in the position of Besuki in the fish trade. Previously, to meet local needs the region always depended on fish imports. But from the 1930s the region began to export fish products. In 1936 a total of 439 tons of fish was transported from Banyuwangi to Surabaya and by 1937 it increased to 2,241 tons [25]. In 1941 the Borsumij firm was reported to have exported a significant quantity of canned fish from Banyuwangi [41]. During the tumultuous years of the 1940s the output of the region's fisheries seems to have declined. A set of factors regarded as responsible for the decline in East Java, probably including Besuki, were the decrease in fishing boats and gear due to the 'scorched earth' policy before the Japanese invasion, the difficulty in obtaining timber for boat renewals, and fishing restrictions at night imposed by the Japanese [42].

With the improved political stability from the late 1940 s, the region's fisheries revived. A steep increase in catches between 1949 and 1950 might have stemmed from the increase in fishing operations and better stocks linked to years of under-exploitation. If the data for the whole of East Java for the 1955-1960 period are any indication, the catches in Besuki might have slightly and steadily increased until 1960 [43]. But the catches of lemuru in Muncar for the same period suggest the opposite. There is a rather similar trend between lemuru catches in Muncar and total catches in Besuki, which might suggest that between 1955 and 1960 the catches in Besuki were constantly low. A significant increase began from 1963 with a peak catch in 1968 , reaching 23,000 tons $[41,43,44]$. In 1968 the catches landed in Banyuwangi alone constituted nearly 70 per cent of East Java's total catches, while the proportions of fishers and fishing vessels in this regency were only 8 per cent and 11 per cent [45]. The increase in catches in the 1960s seems to have stemmed from the significant improvement in fishing technology.

\section{B. Fishing Technology}

The Technology is one of the major factors enabling the fisheries extraction. Butcher calls it as 'the art of fishing'. This embraces three key elements: fishing boats, fishing equipment, and practical knowledge [9]. 
The fishing boats in the Besuki region were not uniform. A traditional literature from Banyuwangi mentions mayang canoe (kano mayang), mancing proa, and jorong proa [51]. Hageman [46] noted two types of fishing boat in Jember: proa (perahu) and outrigger canoe (jukung). The early 1900s colonial report identified four types of fishing boats: kolek, sampan, jrupih, and jukung. The first three boats basically had something in common in the sense that they were made from wooden boards with diverse bows and stern shapes. The names reflected their sizes. The largest fishing boat was called kolek, and had a length of around 8 meters, a width of 2.25 meters with 7-8 sailing crew. The other boats, sampan and jrupih, were smaller in terms of size and crew capacity [13]. Meanwhile, outrigger canoes (jukung) were directly shaped from a wood beam, occasionally heightened by adding a couple of wooden boards [47].

In terms of operation area, the fishing boats in Besuki can be broadly grouped into two categories. The first category was mayangan, which was used for a deep-sea fishing operation $[25,48]$. In Besuki what was called kolek was a mayangan [13]. This boat often had different names across Java, such as konting, besse, kolekan, potik, and menting [47]. The second category was non-mayangan, including jukung, sampan, jrupih. They were used for coastal fishing operations [25,49]. Between 1895 and 1952 the two types of fishing boats grew in number. The mayangan type doubled, whereas the non-mayangan type rose by more than 50 per cent. The mayangan boats made up roughly 10 per cent of the total fishing boats in 1895 , and it grew to 13 per cent by 1952 . The non-mayangan predominated among the region's fishing vessels [13,41].

Despite the difference in size, there was one major similarity. All fishing boats relied heavily on the daily pattern of sea breezes as a source of power to go to and from fishing grounds. The ways in which the Indonesian fishing boats of Besuki operated seem to have been essentially similar to the early $19^{\text {th }}$ century descriptions by Raffles. The fishing boats usually departed from the shore in the very early morning by utilizing the off-shore winds and returned in the afternoon by relying on the on-shore sea breezes [50]. The breezes were caught with sail, made initially from corypha palm fibers (agel), but later also from cloth [47]. The use of sail was common among the local fishers.

Each type of fishing boat had different equipment. Deep-sea fishers used a large sack-like net with two long wings (payang), especially during the layang season [41]. This kind of net, which could reach 180 meters in length and 120 kilograms in weight, was made from agel rope [52]. The agel-producing trees grew in the region's forest and were regarded by the local inhabitants as among its most valuable products [18]. The fishing operation was frequently aided with rumpon, a floating fish lure consisting of a long rope with sinkers along one edge and floats on the other to support it upright in the water. Along the rope were bound coconut leaves, as hiding places to attract fish. Fish schools were periodically captured, first by lifting up the rumpon). Besides layang as a major catch, a variety of fish was captured in the operation [41]. Outside the layang season, the deep-sea fishers used gill nets and fishing rods [25]. There was a variety of equipment for coastal fishing such as jaring jabur (also called payang pinggir), krakat, jala, and also fishing traps such as bubu and cager [41]. The major catches came from the use of jaring jabur, a payang-like net but finer and smaller in size, suitable for capturing small fish and shrimps $[52,53]$.

The above fishing technologies were combined with practical knowledge too. The local fishers were described as having a good knowledge of how to identify fishing grounds, to understand sea currents, fish behavior, and the right time to throw nets [24]. On the region's north coast, the fishing grounds were usually recognized from constellations and natural landmarks such as the position of volcanoes seen from the various locations. In determining the fishing and off-fishing seasons, the time for starting and ending operations, the fishers adopted the lunar calculation system [54].

From circa 1910 there had been experiments with new fishing technology such as larger and finer nets and motorized boats [55]. In Besuki around 1920 there was a pioneering fishing venture employing motorized boats and large nets in the Madura Straits run by Dietz, taking inspiration from the European fisheries. The venture, however, soon ceased to operate due to poor engine quality and difficulties in renewing spare parts [24]. An attempt was made by the Zeevisserij-Instituut (Sea Fishery Institute) to equip mayangan boats with motor power [56]. But there was no evidence that in the 1930s the motorequipped fishing boats that were already in use around Jakarta were also present in Besuki [53]. One reason behind this slow development was that capital was too expensive relative to labor. Unsurprisingly, the fishing boat motorization, which later took place, often had to be encouraged through foreign aid development projects [57]. Among the local fishers there were beliefs that the use of motor-equipped boats would scare fish and reduce catches because of engine noise. In the 1950s the motor-equipped fishing boats were still on trial in the Surabaya-based marine fishing station. Limited capacity and less developed technology were reported still common among the local fishers along the coast of East Java from Bangil to Banyuwangi [58]. 
Of course, several changes did take place. Initially, the region's fishers attracted fish with torches. But from 1950 the use of kerosene lanterns, which were believed to attract more fish gatherings, thereby promoting better catches, developed in Banyuwangi [58]. This practice apparently became more common in the 1960s [59]. From around 1960 some fishers in Banyuwangi adopted the lift-net (bagan). Brought by the Buginese migrants to the region in the late 1950s, the lift-net became popular in Pangpang bay [60]. Despite these facts, it can be said that prior to the New Order period the fishing technologies employed by the local fishers only facilitated the increased extraction of fish resources in the traditional fishing grounds, but without having the effect of expanding the fishing frontier. Only from around 1968 onwards did a new trend begin to grow parallel with the adoption of motorised fishing vessels and nylon purse seine nets and reached its fullfledged development from the mid-1970s [61]. This technology gave access to new fishing grounds that had previously remained inaccessible to the local fishers. designations.

\section{CONCLUSION}

This article has indicated the growing importance of fishery sector in the Besuki region during the preNew Order period. The most discernable outcome of the growth was the shift in the region's center for marine fisheries from the northern coast of Panarukan to the eastern coast of Banyuwangi centering in Muncar, which became the second largest fishing complex in Indonesia. As a result, there was a radical change in the position of Besuki in the fish trade. In order to meet local needs, the region had long depended largely on fish imports from other places especially the Sapudi and Kangean islands of Madura. But from the 1930s the region began to export fish products to outside market. This feature provides a more complete historical picture of the region that the development of the eastern salient of east Java was not only observable in the field of export agriculture, but also in the fisheries sector.

Apart from the rapidly growing population size and the development of export agriculture contributed to the creation of a bigger local market for fish products, the increase in number of fishing vessels played a major role in promoting the catches among the local fishers. Meanwhile, the improvement of the art of fishing seem to have run quite slowly and as a result, the role of the technologies in promoting fish catches remained less remarkable. Only after the adoption of the fishing modernization, the extraction of fish resources entered a new era characterized by a growing trend in catches, which also affected the structure of production relations in the region's fisheries sector.

\section{REFERENCES}

[1] Malang Post, 19 January 1952.

[2] J.A.C Mackie, "The Changing Political Economy of an Export Crop: The Case of Jember"s Tobacco Industry," Bull. Indo. Ec. Stu. Canberra, vol.21,1985, pp. 113-138.
[3] Nawiyanto, Agricultural Development in a Frontier Region of Java Yogyakarta:, Galang Press, 2003.

[4] S. Padmo, The Cultivation of Vorstenlands Tobacco in Surakarta Residency and Besuki Tobacco in Besuki Residency and Its Impact on the Peasant Economy and Society. Yogyakarta: Aditya Media, 1994.

[5] D.K. Emmerson, "Biting the Helping Hand: Modernization and Violence in an Indonesian Fishing Community," Land Tenure Center Newsletter, vol. 51, 1976, pp. 1-15.

[6] D.K. Emmerson, "Orders of Meaning: Understanding Political Change in a Fishing Community in Indonesia," In Interpreting Indonesian Politics, B. Anderson (ed.), Ithaca: Cornell Modern Indonesian Project, 1982, pp. 149-163.

[7] S. Budhisantoso, Kehidupan Masyarakat Nelayan di Muncar Kabupaten Banyuwangi Propinsi Jawa Timur. Jakarta: Departemen Pendidikan dan Kebudayaan, 1991.

[8] Kusnadi, Nelayan: Strategi Adaptasi dan Jaringan Sosial. Bandung: Humaniora Utama Press, 2000.

[9] J.G. Butcher, The Closing of the Frontier: A History of the Marine Fisheries of Southeast Asia c. 1850-2000. Singapore: Institute of Southeast Asian Studies, 2004

[10] T.F. Flannery, The Future Eaters: An Ecological History of the Australasian Lands and People. Sydney: New Holland Publishers, Sydney, 1994/1997.

[11] W.C.A.Vink, Verslag de Verichtingen van het Onderzoekingsvaartuig voor de Visscherij over 1911. Batavia: Mededeelingen van het Visscherij-station te Batavia, 1912.

[12] R.R.H. Suratmi, "Migrasi Suku Bugis di Muncar Tahun 19741979," unpublished.

[13] Onderzoek, Onderzoek naar de Mindere Welvaart der Inlandsche Bevolking op Java en Madoera. Batavia: Landsdrukkerij, 1905.

[14] Survey Sosial, Survey Sosial Ekonomi Budaya di Daerah Pantai Pulau Jawa Sebelah Utara dan Banyuwangi," unpublished.

[15] J. Tennekes, "De Bevolkingspreiding der Residentie Besoeki in 1930," Tijd. Kon. Ned. Aard. Gen. Netherlands, vol. 80, 1963, pp. 309-423.

[16] BPS. Penduduk Indonesia: Registrasi 1968. Djakarta: Biro Pusat Statistik, 1971.

[17] G.N. Verloop, "Zeevisscherij Naast de Inlandsche Landbouw," Tijd. Nij. Land. Ned., Netherlands, vol. 69, 1904.

[18] ANRI, Algemeen Verslag Besuki, 1882, 1883, 1888, unpublished.

[19] R. Wessing, "Nyai Roro Kidul in Puger: Local Applications of a Myth," Archipel, Paris, vol. 53, 1997, pp. 97-120.

[20] ANRI, "Memorie van Overgave van den Resident van Besoeki, Ch. A. van Romondt over de Periode 30 Januari 1935-26 Februari 1938", unpublished.

[21] D.S. Slamet, "Pokok-Pokok Pikiran dan Perentjanaan Pembangunan Perikanan Laut Muncar," unpublished.

[22] A. Dwiponggo, "Beberapa Aspek Biologi Ikan Lemuru, Sardinella spp," In Prosiding Seminar Perikanan Lemuru, Pusat Penelitian dan Pengembangan Perikanan Departemen Pertanian, 1982, pp. 75-89.

[23] Dinas Perikanan, Laporan Tahunan 1973. Surabaya: Dinas Perikanan Daerah Propinsi Jawa Timur, 1974.

[24] G. Dietz, "Why Did the Labuan Mrak Fail?," Inter-Ocean, vol. 4(5) , 1923, pp. 285-292.

[25] Masyhuri, Pasang Surut Usaha Perikanan Laut: Tinjauan Sosial-Ekonomi Kenelayanan di Jawa dan Madura, 1850-1940. Amsterdam: Vrije Universiteit, 1995.

[26] F. Sudjanadi, "Laporan Praktek Ko-operasi Tingkat Sardjana di Kabupaten Banyuwangi dari Tanggal 8 Februari 1956 s/d 8 Maret 1956," unpublished.

[27] Dana, "Dana Kecelakaan Laut," Ber. Per, Indonesia,vol. 4 (34), 1952, p. 50.

[28] P. Semedi, "Political Life of Javanese Fishermen," Masy. Indo. Indonesia, vol. 28 (1), 2002, pp. 55-79. 
[29] D. Rato, "Prahu Madura: Ritual Pembuatan dan Simbolisme Hiasannya, Studi Kasus di Puger dan Besuki,” unpublished.

[30] A.L.J. Sunier, De Beteekenis van het Natuurwetenschappelijk Visserij-onderzoek voor Nederlandsch-Indië. Batavia: Mededeelingen van het Visscherij-station te Batavia, 1914.

[31] A.W. Schippers, , "De Zeevisscherijen van Nederlandsch Indie," Kol. Tijds. Netherlands, vol. 17, 1928, pp. 15-37.

[32] P.A. de Nijs Bik, "Visserij in Nederlandsch-Indië," Kol. Tijds. Netherlands, vol. 1(3), pp. 86-92.

[33] Nawiyanto, "Pertumbuhan Penduduk Besuki: Kajian Demografi Historis,” J. Hum. Indonesia, vol. 21(2), 2009, pp. 174-187.

[34] Ch.O. van der Plas, "De Visscherij en de Vischhandel in den Kangean-en Sapoediarchipel,” Kol. Tijds. Netherlands, vol. 9, 1920, pp. 518-570, 611-632.

[35] Rifvisserij, "Rifvisserij," Viss. Batavia, vol. 1(4) , 1949, p. 9.

[36] M.D. Burkenroad, "The Development of Marine Resources in Indonesia," Far East. Quart, vol. 5 (2) , 1946, pp. 189-199.

[37] A.W.C.T. Herre, "Research on Fish and Fisheries in the IndoAustralian Archipelago," In Science and Scientists in the Netherlands Indies: P. Honig, Ed. New York: Board of the Netherlands Indies, Surinam, and Curaçao, 1945, pp. 167-175.

[38] R. Broersma, Besoeki: Een Gewest in Opkomst. Amsterdam: Scheltema, 1912.

[39] R. Broersma, "Westersche Zeevisscherij voor Ned.-Indië," Kol. Tijds Netherlands, vol. 16, pp. 454-462.

[40] W. Subani, "Masalah Perikanan Lemuru di Selat Bali," Tindj Ek. BNI, Indonesia, vol. 5(38), 1971, pp. 18-22.

[41] Kementerian Penerangan, Republik Indonesia: Propinsi Djawa Timur. Surabaja: Djawatan Penerangan Propinsi Djawa Timur, 1953

[42] M.W. Wirjodihardjo, Bijzonder Welvaartsplan 1949. Batavia: Mededelingen van de Departementen van Economische Zaken \& Landbouw en Visserij in Indonesië, 1949

[43] BPS, Hasil Penangkapan Ikan Laut di Jawa dan Madura dalam Tahun 1955-1962. Djakarta: Biro Pusat Statistik, 1964.

[44] BPS, Produksi Perikanan Laut Yang Dijual di Pelelangan/Tempat Pendaratan Ikan di Jawa-Madura: 19651973. Jakarta: Biro Pusat Statistik, 1975.

[45] A. Suadi and Budianto, "Contour-Study Djawa Timur," unpublished.
[46] J. Hageman, "Over de Nijverheid in Zuidoostelijk Java," Tijds. Nijv. Land. Ned. Ind., vol 8,1862, pp. 27-66.

[47] P.N. van Kampen, Overzicht der Hulpmiddelen bij de Zeevisscherij van Java en Madoera in Gebruik. Batavia: Department van Landbouw, 1908

[48] A. Horridge, The Prahu: Traditional Sailing Boat of Indonesia. Oxford: Oxford University Press, 1981.

[49] C. Nooteboom, De Boomstamkano in Indonesie. Leiden: Brill, 1932.

[50] T.S. Raffles, The History of Java. Oxford: Oxford University Press, (1817/1978).

[51] A. Aminoedin, H. Widodo, M. Hasan, Z. Suryawinata, Penelitian Bahasa dan Sastra Dalam Naskah Cerita Sri Tanjung di Banyuwangi. Jakarta: Departemen Pendidikan dan Kebudayaan, 1986.

[52] R. Pranjoto, "Luas dan Sifat Perikanan Laut di Indonesia," In Almanak Pertanian 1953, Djakarta: Badan Usaha Penerbit Almanak Pertanian, 1953, pp. 249-259.

[53] H.C. Delsman, "Fishing and Fish-Culture in the Netherlands Indies," Bull. Col. Inst. Amst. Netherlands, vol. 2, 1938-1939, pp. 92-105.

[54] S. Budhisantoso, Kehidupan Masyarakat Nelayan di Muncar Kabupaten Banyuwangi Propinsi Jawa Timur. Jakarta: Departemen Pendidikan dan Kebudayaan, 1991.

[55] S. Krisnandhi, "The Economic Development of Indonesia's Fishing Industry,” Bull. Ind. Econ Stu. Canberra, vol. 5 (1), 1969, pp. 49-72.

[56] S.J. de Groot, "Het Zeevisserij-Onderzoek in Nederlands-Indië 1904-1949,” Med. Ned. Ver. Zee. Netherlands, vol. 26, 1973, pp. 43-52.

[57] Upacara, "Upatjara Penjerahan Perahu Motor Majang dari E.C.A. Kepada Perikanan Laut Indonesia," Ber. Per. Indonesia, vol. 3 (5-6), pp. 83, 195.

[58] Malang Post, 26 May 1952.

[59] I.P. Sedana, "Penelitian Tentang Tingkah Laku Ikan Terhadap Lampu-lampu Berwarna,” Terubuk, 2(6) , 1976, pp. 8-24.

[60] I.G. Merta, Sedana, M. Badrudin, "Dinamika Populasi dan Pengelolaan Sumberdaya Perikanan Lemuru di Perairan Selat Bali,” J. Pen. Per. Indonesia, vol. 65, 1992, pp. 35-44.

[61] K. Adiwiredja, "Perikanan Lumuru di Selat Bali," Terubuk, Indonesia, vol. 9 (25), 1983, pp. 22-30. 